"Performance implications of financial capital availability on the financial literacy - performance nexus in South Africa"

\section{AUTHORS}

ARTICLE INFO

DOI

RELEASED ON

JOURNAL

FOUNDER
Neneh Brownhilder Ngek

Neneh Brownhilder Ngek (2016). Performance implications of financial capital availability on the financial literacy - performance nexus in South Africa. Investment Management and Financial Innovations, 13(2-2), 354-362. doi:10.21511/imfi.13(2-2).2016.10

http://dx.doi.org/10.21511/imfi.13(2-2).2016.10

Thursday, 14 July 2016

"Investment Management and Financial Innovations"

LLC "Consulting Publishing Company "Business Perspectives"
NUMBER OF REFERENCES

0

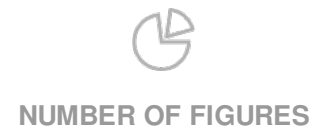

0

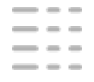

NUMBER OF TABLES

0

(C) The author(s) 2023. This publication is an open access article. 
Neneh Brownhilder Ngek (South Africa)

\title{
Performance implications of financial capital availability on the financial literacy - performance nexus in South Africa
}

\begin{abstract}
The need for making optimal financial decisions is very important in small and medium enterprises (SMEs) especially as most SMEs are always financially constrained. Consequently, there has been an increasing interest from researchers to determine how well financial literacy skills can enable entrepreneurs to make decisions that result in optimal financial outcomes and possible enhance the performance and growth of their businesses. This study had as objectives to find out the impact of financial literacy on firm performance, as well as to examine the moderating effect of financial capital availability on the financial literacy - performance relationship, amongst SME in the Free State province of South Africa. The results showed that on average SME have low levels of financial literacy and financial capital availability. It was also observed that financial literacy positively influenced SME performance, and that the relationship is positively moderated by financial capital availability. It is, therefore, necessary for SME owners to develop financial literacy skills as an essential part of entrepreneurial activities. Likewise, since businesses rely on financial capital to invest, develop and grow, policy makers should put in place measures on how to bridge the access to finance gap, and, thus, ensure that entrepreneurs are relieved from financing constraints.
\end{abstract}

Keywords: financial literacy, financial capital availability, SMEs, firm performance, South Africa. JEL Classification: M13, L25, D12.

\section{Introduction}

Entrepreneurs are always routinely involved in the decision-making activities of their businesses such as resource acquisition, allocation, and utilization, savings, investments, and retirement planning, etc. All these activities, most of which involve the day to day running of the business always have financial consequences for the entrepreneur/business (Oseifuah, 2010). Drexler, Fischer and Schoar (2014) expound that both individuals and entrepreneurs are usually confronted with difficult financial decisions in many aspects of life, be it in their personal finances or as business owners. As such, financial literacy becomes vital in the financing decisions of their business and their subsequent performance (Oseifuah, 2010; Adomako and Danso, 2014). Financial literary can be defined as the bulk of knowledge and cognitive capabilities necessary for managing and making effective decisions regarding the handling of finances such as budgeting, bookkeeping, bills and utilities payments, loan acquisition and payments and other financial decisions (Adomako, Danso and Damoah, 2016; Reich and Berman, 2015). Xiao (2008) views financial literacy as the knowledge about behaviors that are relevant and pertinent in money management which takes into consideration knowledge of income, money management, saving and investing, and spending and credit. Existing empirical studies (Lusardi and Mitchell, 2007; Adomako and Danso, 2014; Lusardi and Tufano, 2009; Fatoki, 2014; Cole, Sampson and Zia, 2009) highlight low levels of financial literacy among advanced and emerging economies, as very few

(c) Neneh Brownhilder Ngek, 2016.

Neneh Brownhilder Ngek, Dr., Senior Lecturer, Department of Business Management, University of the Free State, South Africa. people have an understanding of basic financial concepts. Atkinson (2014) identified financial literacy as one of the common problems small businesses in the US struggle with, as they start and grow their businesses. Kim (2000) observed that many entrepreneurs lack the basic financial knowledge to make effective financial choices and, thus, suggest that if these entrepreneurs are illiterate regarding their personal finances, the financial management of their businesses will also be lacking and, thus, will reduce the creation rate of new ventures and possible increase the failures rates amongst SMEs. Adomako and Danso (2014) explicate that the entrepreneurial activities of a business are jeopardized when the entrepreneur does not possess the relevant skills required to manage their finances effectively. Consequently, Vacher (2014) argues for the need for financial literacy to become part of every businesses culture.

There has been a vast array of empirical research (Lusardi and Mitchell, 2007; Lusardi and Tufano, 2009; Lusardi, Michaud and Mitchell, 2013; Cole, Sampson and Zia, 2009) suggesting a strong nexus between financial literacy and household wellbeing. In the same line, studies have found a positive relationship between financial literacy and firm performance (Drexler, 2010; Siekei, Wagoki and Kalio, 2013; Njoroge, 2012). Nevertheless, despite this scholarly research, there is a dearth of empirical evidence on the impact of the entrepreneurs' financial literacy on business performance especially in a developing country like South Africa. Prior studies on financial literacy in South Africa, for example, Kotze, and Smit (2008) examined how personal financial literacy and personal debt management influenced new venture creation; Oseifuah (2010) examined the financial literary among youth entrepreneurs, while 
Fatoki (2014) measured the level of financial literacy of the owners of new micro enterprises.

In an attempt to fill this gap, this study argues that the effect of financial literacy on firm performance is dependent on the financial capital availability of the business. This is because, while it is evident that financial literacy helps entrepreneurs to make better decisions (Lusardiand Mitchell, 2007), those decisions have to be made in the light of the available capital resources. Adomako and Danso (2014) even argued that financial knowledge without financial capital could play little or no role in influencing the success of an entrepreneurial venture. Hence, this study has as objective to find out the impact of financial literacy on firm performance, as well as to examine the moderating effect of the financial capital availability on the financial literacy - performance relationship. The study will determine the relationship between financial literacy and firm performance and further establish the contingent role of financial capital availability. To augment our knowledge on this contingent relationship, we focus on the resourcebased view (RBV) to explain the beneficial effects of financial capital availability on the relationship between financial literacy and firm performance, hypothesizing that the relationship between financial literacy and firm performance is positively moderated by financial capital availability. By doing so, this study adds further evidence to the growing literature on financial literacy and entrepreneurial firms.

\section{Literature review}

1.1. Resource based view (RBV) theory. The RBV postulates that firms can gain and sustain a competitive advantage by deploying a bundle of resources tangible and intangible assets and organizational capabilities (Barney, 1991; Penrose, 1959; Grant, 1991). Some researchers (Barney, 1991; Wade and Hulland, 2004) contend that, within theoretical frameworks, rival firms compete on the basis of their resources and internal characteristics, through which they build a competitive advantage and a superior long-term performance. Kraaijenbrink, Spencer and Groen (2010, p. 349) put forth that the RBV "aspires to explain the internal sources of a firm's sustained competitive advantage." In this light, organizational performance is the result of firm-specific resources and capabilities enabled by management competencies (Chandler and Hanks, 1994). Therefore, the core of the RBV is that businesses should have a mixed bag of resources, rooted in a set of functional policies and activities, in order to maximize the full potential success of a business (Kelliher and Reinl, 2009). Hence, using the RBV, this study examines the performance effects of a firm's financial capital availability on the financial literacy - performance relationship of entrepreneurial firms in South Africa.
1.2. Financial literacy and firm performance. The growing importance of financial literacy has attracted attention from researchers and policy makers. Over the past years, most research on financial literacy have focused on the relationship between financial literacy and financial decision-making (Lusardi and Mitchell, 2011; Yoong, 2011; Smith, McArdle and Willis, 2010; Van Rooij, Lusardi and Alessie, 2011). Lusardi, Mitchell and Curto (2010) expound that the increased attention on financial literacy is attributed to the importance of saving for retirement. Greenspan (2002) established that financial literacy teaches individuals the financial knowledge necessary to create household budgets, initiate and practice savings plans, and make strategic investment decisions. Stango and Zinman (2007) note that individuals who are unable to correctly calculate interest rates out of a stream of payments turn to borrow more and, consequently, accumulate lower amounts of wealth.

With regards to firm performance, researchers (Kotze and Smit, 2008; Oseifuah, 2010; Fatoki, 2014) have established that the success and performance of SMEs depends on their ability to manage financial issues effectively. Fernandes (2015), in her study on financial literacy levels of small businesses in Portugal, found that the small businesses owners had a low financial literacy level. Also, this study established that higher the level of financial literacy amongst the small business owners, the better the performance of their businesses and thus recommends that in order to improve the level of financial literacy, adequate program on financial education should be put in place. Drexler et al. (2010) established that the more financial literate the SME owner is, the higher the chances that his/her business will succeed. Bruhn and Zia (2011) found entrepreneurs with high levels of financial literacy showed better business performances. Njoroge (2012) found a positive relationship between financial literacy and firm performance. Siekei et al. (2013) observed that SME owners with high levels of financial literacy have higher chances of being successful compared to their financial illiterate counterparts, as their businesses were seen to perform better. Following from the above discussion, it is expected that the financial literary of an entrepreneur will positively influence the performance of his/her business venture.

\section{Moderating effect of financial capital availability}

While some researchers (Bruhn and Zia, 2011; Drexler et al., 2010; Godfrey, Levesque and Stark, 2009) emphasize that financial literacy is a vital tool for managing business finance and enhancing the business performance, Adomako and Danso (2014) argue that SMEs owners possessing adequate financial knowledge may not certainly transform it 
into firm performance without access to funding, as financing is an important part of operating any business. Without sufficient access to financing, the operating power of any business and its potential for growth is at risk. Coleman (2007) defines financial capital as the funds that come from the family in business, extended networks, and from commercial banks or other financial institutions or equity infusion from external sources. Financial capital can come either from internal or external sources. Given that the amount of initial capital is often related to the initial strategy that might be pursued, SMEs in developing countries usually depend heavily on informal sources of financing from family members, friends, and money lenders. However, given that not all SMEs are able to acquire the required capital by internal funding, they are often forced to seek external funding which is not readily available to most SMEs.

The need of financial capital for firm formation has been well researched (Backman, 2013; Beck, Demirguc-Kunt and Peria, 2008; Smit and Fatoki, 2011). Clarke, Seng and Whiting (2010) provide empirical evidence that financial capital positively impacts on firm performance. Access to financial capital is a critical resource necessary for achieving the objectives of a business such as growth and performance, as well as the realization of development and innovation activities (Sexton and Bowman-Upton, 1991; Adomako and Danso, 2014). As such, businesses rely on financial capital to invest, develop and grow. Inmyxai and Takahashi (2010) established that business finance is an important factor used to finance strategic resources, restructure and or expand the business in accordance with the objectives of the business of profit maximization. Barney (1986) elucidates that businesses need sufficient financial capital in order to support the implementation of internal growth strategies and also to gain a competitive advantage via superior returns. Dollinger (1999) established that financial capital is the most generic type of resources that can easily be converted into other types of resources. Having a suitable financing strategy is vital to achieve business success as the key to success in small-scale business is the amount of initial investment and on-going access to finance (Yusuf, 1995). Nonetheless, Brush, Greene, Hart and Edelman (1997) observed that due to financial capital constraint, many innovative products and services may never reach the market. Moreover, financial capital provides businesses with the slack to pursuit of resource-intensive growth strategies and experiment with innovative projects and new strategies that would, otherwise, be impossible to undertaken in a more resource-constrained environment (Mousa, 2009; Cyert and March, 1992). Drawing from the above, it can be established that access to finance is particularly important, as it plays a twin role by facilitating the development of start-ups and also provide a signal about the quality of future growth potential, which, in turn, reduces the external financing constraints for businesses facing informational problems (Adomako and Danso, 2014). Hence, we argue that financial resource availability allows a business access to finance that may be difficult to obtain in terms of collateral requirements, but that also have better probability of succeeding. As such, it can be seen that financial resource availability is more likely to augment the relationship between financial literacy and firm performance, such that this relationship becomes more positively correlated with firm performance under high levels of financial capital availability. Consequently, financial capital availability is expected to positively moderate the relationship between financial literacy and firm performance.

\section{Methodology}

3.1. Sample and data collection. In this study, data were collected using self-administered questionnaires. The sample consists of entrepreneurs in the Mangaung metropolitan municipality in the Free State province of South Africa. Convenience sampling method was adopted and supplemented with snowball sampling owing to the lack of a database of entrepreneurs in the Free State and South Africa in general. The respondents were identified from the Yellow pages directory and, then, visited at their specific business locations. A total of 300 questionnaires were administered to the entrepreneurs, of which 200 were fully completed and returned resulting in a valid response rate of $66.7 \%$.

\section{Variables and measures}

4.1. Financial literacy. There is no standardized measure of financial literacy, as different studies make use of different measurement. For example, Dahmen and Rodríguez (2014) measured financial literacy using four items: we prepare monthly company financial statement (income statement and balance sheet; we review monthly financial statements; we perform financial analysis on monthly financial statements; we have an understanding of the company's gross profit ratio and its contribution to the overall profit. Wise (2013) and Oseifuah (2010) measure financial literacy using mathematical and computer literacy, financial behavior financial attitude and financial knowledge. Sucuahi (2013) used record-keeping, budgeting savings, and financial skills to measure financial literacy. Fatoki (2014) used financial planning, budgeting and control, bookkeeping, understanding of funding sources, business terminology, finance and information skills, use to technology and risk-management (insurance). 
Following from these different definitions, it is evident that preparing and keeping financial records is an important measure of financial literacy. Consequently, this study adopted bookkeeping as the measure of financial literacy as used by other studies in South Africa (e.g., Fatoki, 2014). Additionally, bookkeeping has been widely recognized as a measure of financial literacy. For example, the CRESSI project by SAID business School in the University of Oxford uses bookkeeping as the basis for teaching financial literacy (Budd, 2015). Bookkeeping is believed to be the basics of business, the foundation, where a business can "speak" and, thus, considered the primary place where financial literacy starts. Bookkeeping enables SME owners/managers to extract financial information about their businesses regarding aspects like sales, purchases, debtors, creditors, expenses and the general financial health, of the business amongst others (Seeds for change, 2013).

4.2. Access to financial capital. Following from prior studies (Cooper, Gimeno-Gascon and Woo, 1994; Wiklund and Shepherd, 2005), this study measured financial capital availability using a subjective measure of the SME owner/manager's level of satisfaction with his/her access to financial capital. This factor was measured on a five point Likert scale with the opposite statements "insufficient and a great impediment for our development" for 1 and "fully satisfactory for the firm's development" for 5 .

4.3. Control variables. In this study, the firm size and firm age were used as control variables because they both have an impact on a firm's performance. Firm size is an important determinant of firm performance and survival and can reflect past success and may also influence current performance of the firm (Mukhtar, 2002; Ravichandran and Lertwongsatien, 2005; Inmyxai and Takahashi, 2010). Likewise, the firm's age is also a vital factor that affects firm performance. While older firms appear to be larger in terms of sales turnover, capital assets and number of employees, younger firms seem to have lower sales and as a result lower profits (Watson, 2002). Consequently, a firm's age denotes the power and experience a firm has in a chosen industry, which can, thus, be influential to the firm's performance (Inmyxai and Takahashi, 2010). The importance of these two factors as control variables have also been documented in prior studies (e.g., Adomako and Danso, 2014; Neneh and Van Zyl, 2014).

4.4. Firm performance. Given that SME owners/managers often refuse to provide accurate, objective performance data to researchers, it becomes difficult to obtain objective firm financial data. In the case where objective data are provided, the data often do not fully represent the actual performance of the firm, as SME owners/managers may sometimes manipulate the data to avoid personal or corporate taxes (Zulkiffli and Perera, 2011; Kimatu and Bichanga, 2015). Consequently, a firm's performance is measured using subjective measure that can reflect more specific objective measures (Wall, Michie, Patterson, Wood, Sheehan, Clegg and West, 2004). As such, in this study, selfreported measures were adopted for measuring firm performance. Firm performance was measured through three different items (growth in the number of employees; growth of market share and sales growth) where the respondents were asked to compare their firms' performance to that of competitors, as used in prior studies (Keh, Nguyen and Ng, 2007; Wiklund and Shepherd, 2005).

\section{Results}

5.1. Descriptive information of respondents. A total of 200 SME owner-managers fully completed and returned the questionnaires which were, then, subject to analysis. $74 \%$ of the respondents were males while $26 \%$ were females. The majority of the entrepreneurs were between the ages of 31-40 and $41-50$, with $46.5 \%$ and $25.3 \%$, respectively. More than $50 \%$ of the owner-managers had only attained an educational level up to matric. Also, $51 \%$ of the respondents had no prior experience before stating their business, and $88.9 \%$ came from a family with an entrepreneurial background.

Table 1. Correlation matrix

\begin{tabular}{|l|c|c|c|c|c|c|c|}
\hline & Mean & SD & $(1)$ & $(2)$ & (3) & (4) & (5) \\
\hline (1) Financial literacy & 1.259 & 0.226 & 1 & & & & \\
\hline (2) Log age & 0.627 & 0.349 & $0.237^{* *}$ & 1 & & & \\
\hline (3) Log size & 0.510 & 0.254 & $0.249^{* *}$ & $0.182^{* *}$ & 1 & & \\
\hline (4) Financial capital availability & 1.650 & 1.363 & $0.538^{* *}$ & $0.151^{*}$ & $0.317^{* *}$ & 1 & \\
\hline (5) SME performance & 2.463 & 0.843 & $0.511^{* *}$ & 0.122 & $0.227^{* *}$ & $0.741^{* *}$ & 1 \\
\hline
\end{tabular}

Source: $* *$ Sig. at $1 \%,{ }^{*}$ Sig at $5 \%$.

Table 1 depicts the descriptive statistics and correlation matrix for financial literacy, firm's age and size, financial capital availability and SME performance. The results show that the mean for financial literacy is 1.259 depicting that on average SMEs have very low levels of financial literacy. This is consistent with findings by Fatoki (2014) which established that most small businesses in 
South Africa do not keep financial records that will allow them to extract useful accounting information. Also, other studies (Amoako, 2013; Agyei-Mensah, 2011 and Maseko and Manyani, 2011) showed that the majority of SMEs do not keep or maintain complete accounting records because of lack of accounting knowledge and, as such, there is inefficient use of accounting information to support the assessment of financial performance. This, in turn, makes it difficult for most SMEs to access finance, as access to financial capital, especially from external sources like banks and micro finance institutions is largely dependent on their quality of accounting information.

Also, the mean for financial capital availability, is 1.650, depicting that on average have low levels of financial capital availability. This is not surprising, as access to financial capital has been singled out as one of the main factors impending the survival and growth of SMEs in South Africa (Mazanai and Fatoki, 2012). Mass and Herrington (2006) expound that many entrepreneurs believe that, although there seems to be adequate funds available in South Africa, it remains difficult, especially for start-up SMEs, to access these funds. This becomes a critical concern, as access to financial capital is a critical resource necessary for developing the SME sector as an engine for job creation, and poverty alleviation, as well as aid in achieving the objectives of a business such as growth, performance and the realization of development and innovation activities (Adomako and Danso, 2014; Mazanai and Fatoki, 2012).

Furthermore, also established is the fact that financial capital availability has a positive correlation with financial literacy, a firm's size and age, while SME performance has a positive correlation with financial literacy, financial capital availability and firm size. This is congruent with the findings of Njoroge (2012), who also found a positive correlation between SME success and financial literacy. The findings also support existing evidence that larger firms and older firms are always more favored in access to finance than younger firms and small firms (Kira and $\mathrm{He}, 2012)$.

Table 2. Results on the moderating effect on financial capital availability

\begin{tabular}{|c|c|c|c|c|c|c|c|c|}
\hline \multirow{2}{*}{ Factors } & \multicolumn{2}{|c|}{ Model 1} & \multicolumn{2}{|c|}{ Model 2} & \multicolumn{2}{|c|}{ Model 3} & \multicolumn{2}{|c|}{ Model 4} \\
\hline & Beta & T-value & Beta & T-value & Beta & T-value & Beta & T-value \\
\hline \multicolumn{9}{|c|}{ Control variables } \\
\hline Constant & & $11.28^{* *}$ & & $11.95^{* *}$ & & $14.49^{* *}$ & & $10.88^{* *}$ \\
\hline Log (Age) & 1.08 & 1.19 & -0.01 & -0.21 & -0.01 & -0.26 & -0.05 & -0.97 \\
\hline $\log ($ Size) & 1.21 & $3.02^{* *}$ & 0.11 & 1.71 & -0.02 & -0.42 & -0.03 & -0.70 \\
\hline \multicolumn{9}{|l|}{ Independent variable } \\
\hline Financial literacy (FL) & & & 0.49 & $7.59^{* \prime}$ & 0.16 & $2.87^{\prime \prime}$ & 0.49 & $5.72^{* *}$ \\
\hline \multicolumn{9}{|c|}{ Moderating variables } \\
\hline $\begin{array}{l}\text { Financial capital } \\
\text { availability (FCA) }\end{array}$ & & & & & 0.66 & $11.55^{* *}$ & 1.07 & $10.79^{*+}$ \\
\hline \multicolumn{9}{|l|}{ Interaction Item } \\
\hline $\mathrm{FL} \times \mathrm{FCA}$ & & & & & & & 0.67 & $4.89^{* *}$ \\
\hline \multicolumn{9}{|c|}{ Model parameters } \\
\hline$R^{2}$ & \multicolumn{2}{|c|}{0.06} & \multicolumn{2}{|c|}{0.27} & \multicolumn{2}{|c|}{0.57} & \multicolumn{2}{|c|}{0.62} \\
\hline Adjusted $R^{2}$ & \multicolumn{2}{|c|}{0.05} & \multicolumn{2}{|c|}{0.26} & \multicolumn{2}{|c|}{0.56} & \multicolumn{2}{|c|}{0.61} \\
\hline F-value (sig.) & \multicolumn{2}{|c|}{$6.11(0.00)^{\star *}$} & \multicolumn{2}{|c|}{$24.43(0.00)^{\star \star}$} & \multicolumn{2}{|c|}{$64.03(0.00)^{* *}$} & \multicolumn{2}{|c|}{$62.05(0.00)^{*+}$} \\
\hline$R^{2}$-change & \multicolumn{2}{|c|}{-} & \multicolumn{2}{|c|}{0.21} & \multicolumn{2}{|c|}{0.30} & \multicolumn{2}{|c|}{0.05} \\
\hline$F$-change & \multicolumn{2}{|c|}{-} & \multicolumn{2}{|c|}{$57.56(0.00)^{\star \star}$} & \multicolumn{2}{|c|}{$133.35(0.00)^{* *}$} & \multicolumn{2}{|c|}{$23.97(0.00)^{* t}$} \\
\hline
\end{tabular}

Source: $* * \operatorname{Sig}$ at $1 \%, *$ Sig at $5 \%$,

The results on Table 2 show the moderating effect of financial capital availability. Model 1 included only the control variables (firm's age and firm size) and the result show that $F$-value is significant $(p \leq 0.05)$ indicating the overall significance of the model. Inmyxai and Takahashi (2010) used firm size and firm age as a control variable and established that, while size was a positive coefficient and statistically significant, firm age had a positive coefficient and was not statistically significant, which is congruent with the findings of this study.
In model 2, the independent variable (financial literacy) was included. The probability of the $F$-value is significant at the $1 \%$ level showing that the overall model is significant and, thus, valuable in predicting firm performance. Also observed is that financial literacy has a positive relationship with firm performance. This is in accordance with studies by Adomako and Danso (2014), who established a positive relationship between financial literacy and firm performance. This also supports the views by several researchers (Njoroge, 2012; Siekei et al., 2013) 
that financial literary is positively associated with business success.

In model 3, the moderating factor (financial capital availability) was added to model 2 . The results indicate that the probability of the $F$-value is significant at the $1 \%$ level, depicting that the overall significance of the model. The addition of financial capital availability factor to the model did significantly affect the model, as the prediction power of the model significantly increases $\left(R^{2}\right.$-change $=30 \% ; F$-change $=133.35 ; p<$ 0.05). Also observed is that financial capital availability has a positive relationship with firm performance. These results indicate that firm performance increases when entrepreneurs are able to access finance with ease. This result is consistent with prior studies (Adomako and Danso, 2014; Clarke et al., 2010), which established a positive relationship between financial capital availability and firm performance. This indicates that financial capital remains a critical resource vital for enhancing the performance of SMEs.

In model 4, the interaction item (FL x FCA) was included in the model. The probability of the F-value showed that the overall model is significant $(F=$ 23.967; $p<0.05$ ), thus, depicting the overall model as a good predictor of firm performance. Also, adding the interaction variable to the model significantly increases the predictability of the model, as depicted by the significance of the $F$-change value. However, the variation explained increased only by $5 \%\left(R^{2}\right.$-change $)$. These results illustrate that financial capital availability has a positive moderating effect on the relationship between financial literacy and firm performance. To advance further interpretations of the moderating effects, the moderating effect graph for financial capital availability is presented below.

Moderating Effect of FCA on the FL - Performance

Relationship

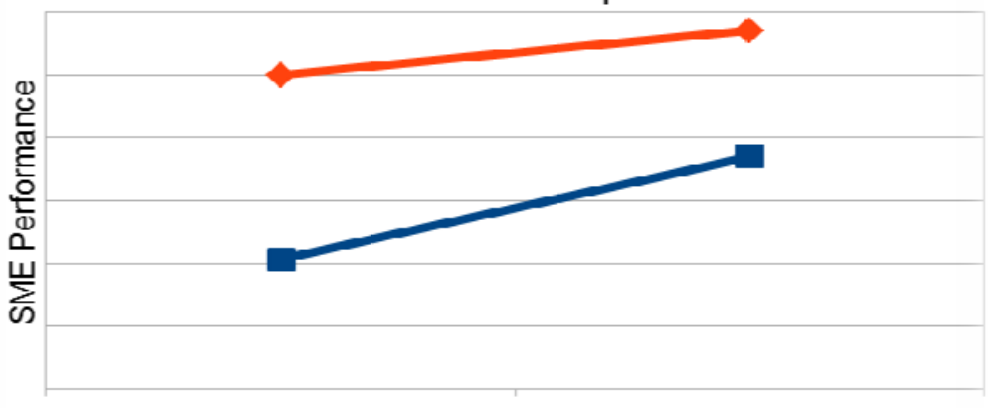

FL

- Low FCA High FCA

Fig. 1.

Figure 1 depicts the interaction between financial literacy and financial capital availability. The findings indicate that firms with high levels of financial capital availability always perform better than firms with low levels of financial capital availability. In other words, when SME owners/mangers have similar levels of financial literacy, the SME owner/manager with more access to finance will outperform the one with low access to finance. The supports the argument by Adomako and Danso (2014) that adequate financial knowledge alone without access to finance may not have a noteworthy effect on firm performance. This indicates that access to finance is a critical resource for firm performance. According to Davidsson and Wiklund (2013), financial capital availability influences firm performance in SMEs, because it provides a buffer effect against unanticipated challenges that could result from internal or external sources. Because of this buffer effect, financial capital availability serves as a moderating factor that helps to strengthen the financial literacy-performance nexus with financial literacy being strongly related to high firm performance when access to finance is high.

\section{Theoretical and managerial implications}

Financial literacy is vital in the financial decision making for entrepreneurs in many aspects of life, be it in their personal finances or as business owners. The identified positive influence of financial literacy on firm performance supports the importance attributed to the concept of financial literacy (Yoong, 2011; Smith, McArdle and Willis, 2010; Van Rooij, Lusardi and Alessie, 2011). In a developing country like South Africa, poor business performance and growth have been attributed to the lack of managerial competencies (Neneh and Van Zyl, 2011). However, financial literacy has not been widely recognized in developing economies as one of the key competencies that could significantly enhance firm performance. This study, therefore, sheds new theoretical and managerial implications in this domain. From a theoretical perspective, there is a need for researchers in developing economies to examine the interplay between financial literacy and SME performance and growth. The close link between the entrepreneur and his/her small business suggest that the entrepreneur's 
financial literacy might directly influence the financial decision making of the firm which, in turn, affects the firm's survivability. From a managerial perspective, the findings in this study suggest the need for SME owners and policy makers in South Africa and other developing economies to start placing more emphasis on acquiring financial literacy skills for entrepreneurs.

Also established is that the financial literacy becomes more positively correlated with firm performance under high levels of financial capital availability. This positive moderating effect of financial capital availability provides valuable theoretical and managerial implications. While the direct effect of financial literacy on performance is very important, this study indicates that financial literacy should not be treated in isolation when examining aspects of firm performance. Failure to consider the role of contingency factors might misguide policy makers on the importance of financial literacy. Evidence from many training programs in developing countries has indicated little or no impact on the performance and growth of SMEs (e.g., Bjorvan and Tungodde, 2012; Karlan and Valdiva, 2011). Consequently, it is imperative that, if policy makers and researchers are to experiment on the impact of financial literacy on enhancing SME performance, they should take into consideration the moderating effect of financial capital availability and probably supplement the financial literacy training with access to funding. As Adomako and Danso (2014) pointed out, simply providing entrepreneurs with adequate financial knowledge alone without access to finance may not have a noteworthy effect on firm performance. As such, entrepreneurs are encouraged to pay more attention not only to financial literacy, but also to concentrate on the ways through which their firms can acquire financial resources, as financial literacy increases firm performance, when the entrepreneurs are able to access finance with ease.

\section{Conclusion}

In conclusion, this study established that, while SME have low levels of financial literacy and financial capital availability, financial literacy positively influenced SME performance, and that the relationship is positively moderated by financial capital availability. Findings from this study have provided valuable theoretical and managerial insights and shed more lights into how financial literacy is an important driver of firm performance and that the relationship between financial literacy and firm performance is positively moderated by financial resource availability and, thus, should be developed as an essential part of entrepreneurial activities. Also, given that businesses rely on financial capital to invest, develop and grow, policy makers should put in place measures on how to bridge the financial gap, and, thus, ensure that entrepreneurs are able to access finance with ease.

\section{References}

1. Adomako, S. and Danso, A. (2014). Financial literacy and firm performance: the moderating role of financial capital availability and resource flexibility, International Journal of Management and Organizational Studies, 3(4), pp. 1-15.

2. Agyei-Mensah, B.K. (2011). Financial management practices of small firms in Ghana: an empirical study, African Journal of Business Management, 5(10), pp. 3781-3793.

3. Amoako, G.K. (2013). Accounting practices of SMEs: a case study of Kumasi Metropolisin Ghana, International Journal of Business and Management, 8(24), pp. 73-83.

4. Atkinson, W. (2014). Small business owners weak on financial literacy. Online, retrieved from: http://www.benefitspro.com/2014/12/08/small-business-owners-weak-on-financial-literacy. Accessed: $24^{\text {th }}$ May, 2016.

5. Backman, M. (2013). Regions, Human Capital and New Firm Formation. Doctoral thesis, Jönköping International Business School, Sweden.

6. Barney, J.B. (1991). Firm resources and sustained competitive advantage, Journal of Management, 17, pp. 99-120.

7. Beck, T., Demirguc-Kunt, A. and Peria, M.S.M. (2008). Bank Financing for SMEs around the World: Drivers, Business Models and Lending Practices. Retrieved from: http://ideas.repec.org/p/wbk/wbrswps/ 4785.html.

8. Bjorvatn, K. and Tungodde, B. (2012). Teaching Business in Tanzania: Evaluating Participation and Performance, Journal of the European Economic Association, 8(2-3), pp. 561-570.

9. Bruhn, M. and Zia, B. (2011). Stimulating Managerial Capital in Emerging Markets: The Impact of Business and Financial Literacy for Young Entrepreneurs, Policy Research Working Paper 5642. [Online]. Available at: file://C:/Users/Brownhilder/Downloads/world-bank-paper-financial-literacy\%20(1)\%20(1).pdf.

10. Brush, C.G., Greene, P.G., Hart, M.M. and Edelman, L.F. (1997). Resource configurations over the life cycle of venture, Frontiers of Entrepreneurship Research, pp. 315-329.

11. Budd, C.H. (2015). Accounting, Social Innovation and Finance - teaching financial literacy using double entry bookkeeping. CRESSI Working Papers, No 15/2015.

12. Chandler, G. and Hanks, S.H. (1994). Market attractiveness, resource-based capabilities, venture strategies and venture performance, Journal of Business Venturing, 9, pp. 331-349.

13. Cole, S., Sampson, T. and Zia, B. (2009). Financial Literacy, Financial Decisions, and the Demand for Financial Services: Evidence from India and Indonesia, Harvard Business School Working Paper 09-117.

14. Coleman, S. (2007). Women-Owned Firms and Growth, Journal of Business and Entrepreneurship, $19(2)$, pp. 31. 
15. Cooper, A.C., Gimeno-Gascon, F.J. and Woo, C.Y. (1994). Initial human and financial capital as predictors of new venture performance, Journal of Business Venturing, 9(5), pp. 371-395.

16. Cyert, R. M. and March, J. G. (1992). Behavioral theory of the firm. Blackwell Publishing.

17. Dahmen, P. and Rodríguez, E. (2014). Financial Literacy and the Success of Small Businesses: An Observation from a Small Business Development Center, Numeracy, 7(1), p. 3. Retrieved from: http://scholarcommons. usf.edu/numeracy/vol7/iss1/art3.

18. Dollinger, M.J. (1999). Entrepreneurship: strategies and resources. Upper Saddle River, NJ: Prentice Hall.

19. Drexler, A., Fischer, G. and Schoar A. (2014). Keeping it Simple: Financial Literacy and Rules of Thumb, American Economic Journal: Applied Economics, 6(2), pp. 1-31.

20. Fatoki, O. (2014). The Financial Literacy of Micro Entrepreneurs in South Africa, Journal of Social Science, 40 (2), pp. 151-158.

21. Fernandes, M.I.T. (2015). Financial Literacy Levels of Small Businesses Owners and it Correlation with Firms' Operating Performance. Master dissertation, Faculdade de Economia do Porto, Portugal.

22. Grant, R.M. (1991). Contemporary Strategy Analysis: Concepts, Techniques, and Applications Blackwell, Cambridge.

23. Inmyxai, S. and Takahashi, Y. (2010). The Effect of Firm Resources on Business Performance of Male- and Female-Headed Firms in the Case of Lao MSMEs, International Journal of Business and Information, 5(1), pp. 63-90.

24. Inmyxai, S. and Takahashi, Y. (2010). The Effect of Firm Resources on Business Performance of Male- and Female-Headed Firms in the Case of Lao MSMEs, International Journal of Business and Information, 5(1), pp. 64-88.

25. Karlan, D. and Valdivia, M. (2011). Teaching entrepreneurship: Impact of business training on microfinance clients and institutions, Review of Economics and Statistics, 93, pp. 510-552.

26. Keh, H.T., Nguyen, T.T.M. and Ng, H.P. (2007). The effects of entrepreneurial orientation and marketing information on the performance of SMEs, Journal of Business Venturing, 22(4), pp. 592-611.

27. Kelliher, F. and Reinl, L. (2009). A Resource-Based View of Micro-Firm Management Practice, Journal of Small Business and Enterprise Development, 16(3), pp. 521-532.

28. Kimatu, K.D. and Bichanga, W.O. (2015). Competitive Strategies and the Non-Financial Performance of Micro Enterprises in Kenya (A Survey of Industrial Knitting Micro Enterprises in Kiambu County), International Journal of Management and Commerce Innovations, 2(2), pp. 160-186.

29. Kira, A.T. and He, Z. (2012). The Impact of Firm Characteristics in Access of Financing by Small and Mediumsized Enterprises in Tanzania, International Journal of Business and Management, 7(24), pp. 108-119.

30. Kraaijenbrink, J. Spender, J.C. andGroen, A.J. (2010). The Resource-Based View: A Review and Assessment of Its Critiques, Journal of Management, 36, pp. 349-372.

31. Lusardi, A. and Mitchell, O. (2011). Financial literacy and planning: Implications for retirement wellbeing. In: A. Lusardi and O. Mitchell. Financial Literacy: Implications for Retirement Security and the Financial Marketplace. Forthcoming Oxford University Press.

32. Lusardi, A. and Mitchell, O.S. (2007). Financial Literacy and Retirement Preparedness: Evidence and Implications for Financial Education, Business Economics, 42(1), pp. 35-44.

33. Lusardi, A. and Mitchell, S.O. (2013). The Economic Importance of Financial Literacy: Theory and Evidence. Retrieved from: http:/www.bancaditalia.it/studiricerche/seminari/2014/economic-importance-financial-literacy/ 20140307_Lusardi_paper.pdf.

34. Lusardi, A. and Tufano, P. (2009). Debt Literacy, Financial Experiences, and Overindebtedness. Dartmouth Working Paper.

35. Maseko, N. and Manyani, O. (2011). Accounting practices of SMEs in Zimbabwe: an investigative study of record keeping for performance measurement (A case study of Bindura), Journal of Accounting and Taxation, 3(8), pp. 171-181.

36. Mazanai, M. and Fatoki, O.O. (2012). Access to Finance in the SME Sector: A South African Perspective, Asian Journal of Business Management, 4(1), pp. 58-67.

37. Miller, M., Godfrey, N., Levesque, B. and Stark, E. (2009). The Case for Financial Literacy in Developing Countries: Promoting Access to Finance by Empowering Consumers. World Bank, DFID, OECD, and CGAP joint note, Washington, DC: World Bank.

38. Mousa, F. (2009). When do slack resources impact new venture success? PHD Thesis, Washington State University, USA.

39. Mukhtar, S. (2002). Differences in male and female management characteristics: a study of owner-manager businesses, Small Business Economics, 18(4), pp. 289-311.

40. Neneh, B.N. and Van Zyl, J.H. (2014). Growth intention and its impact on business growth amongst SMEs in South Africa, Mediterranean Journal of Social Sciences, 5(20), pp. 172-183.

41. Neneh, B.N. and Van Zyl, J. (2012). Achieving optimal business performance through business practices: evidence from SMEs in selected areas in South Africa, Southern Africa Review, 16(3), pp. 118-144.

42. Njoroge, R.N. (2012). Relationship between financial literacy and entrepreneurial success in Nairobi Country Kenya. University of Nairobi. 
43. Oseifuah, E.K. (2010). Financial literacy and youth entrepreneurship in South Africa, African Journal of Economic and Management Studies, 1(2), pp. 164-182.

44. Penrose, E.T. (1959). The theory of the growth of the firm. New York: Wiley.

45. Ravichandran, T. and Lertwongsatien, C. (2005). Effect of information systems resources and capabilities on firm performance: a resource-based perspective, Journal of Management Information Systems, 21(4), pp. $237-276$.

46. Seeds for change.Financial Literacy for Co-operatives. Retrieved from: http://webcache.googleusercontent.com/ search?q=cache:3-XU-M4HCgEJ:seedsforchange.org.uk/financialliteracy.pdf + andcd=1 andhl $=$ enandct $=\mathrm{clnkandgl}=\mathrm{cm}$.

47. Sexton, D. and Bowman-Upton, N. (1991). Entrepreneurship: creativity and growth. New York: Macmillan.

48. Siekei, J., Wagoki, J. and Kalio (2013). An Assessment of the role of financial literacy on performance of small and micro enterprises: case of Equity Group Foundation Training Program on SMES in Njoro district, Kenya, Journal of Economics and Finance (JEF), 1(7), pp. 250-259.

49. Smit, A.V.A. and Fatoki, O.O. (2011). Debt financing to new small ventures in South Africa: The impact of collateral, ethics and the legal system, African Journal of Business Management, 6(3), pp. 1136-1146.

50. Smith, J., McArdle, J. and Willis, R. (2010). Financial decision making and cognition in a family context, Economic Journal, 120, pp. 363-80.

51. Stango, V. and Zinman, J. (2007). Fuzzy Math and Red Ink: When the Opportunity cost of consumption is not what it seems. Mimeo, Dartmouth College.

52. Sucuahi, W.T. (2013). Determinants of financial literacy of micro entrepreneurs in Davao City, International Journal of Accounting Research, 1(1), pp. 44-51.

53. Sucuahi, W.T. (2013). The impact of collateral, ethics and the legal system, African Journal of Business Management, 6(3), pp. 1136-1146.

54. Vacher, H.L. (2014). Review of Financial Intelligence for Entrepreneurs: What You Really Need to Know about the Numbers by Karen Berman and Joe Knight, with John Case, Numeracy, 7(1), Article 8. http://dx.doi.org/10.5038/1936-4660.7.1.8.

55. Van Rooij, M., Lusardi, A. and Alessie, R. (2011). Financial literacy and stock market participation, Journal of Financial Economics, 101(2), pp. 449-472.

56. Wade, M. and Hulland, J. (2004). Review: The Resource-Based View and Information Systems Research: Review, Extension and Suggestions for Future Research, MIS Quarterly, 8(1), pp. 107-142.

57. Wall, T.D., Michie, J., Patterson, M., Wood, S.J., Sheehan, M., Clegg, C.W. and West, M. (2004). On the validity of subjective measures of company performance, Personnel Psychology, 57(1), pp. 95-118.

58. Watson, J. (2002). Comparing the performance of male- and female-controlled businesses: retailing outputs to inputs, Entrepreneurship Theory and Practice, 26(3), pp. 91-100.

59. Wiklund, J. and Shepherd, D.A. (2005). Entrepreneurial orientation and small business performance: a configurational approach, Journal of Business Venturing, 20, pp. 71-91.

60. Wise, S. (2013). The impact of financial literacy on new venture survival, International Journal of Business and Management, 8(23), pp. 30-39.

61. Xiao, J.J. (2008). Handbook of Consumer Finance Research. Ed. New York, NY: Springer.

62. Yoong, J. (2011). Financial illiteracy and stock market participation: evidence from the RAND American Life Panel, in (A. Lusardi and O. Mitchell, eds.), Financial Literacy: Implications for Retirement Security and the Financial Marketplace, pp. 76-100, Oxford: Oxford University Press.

63. Yusuf, A. (1995). Critical success factors for small business: perceptions of South Pacific entrepreneurs, Journal of Small Business Management, 32(3), pp. 68-73.

64. Zulkiffli, S. and Perera, N. (2011). A literature analysis on business performance for SMES - subjective or objective measures? 2011 SIBR Conference on Interdisciplinary Business and Economics Research (pp. 1-9). Bangkok, Thailand: Society of Interdisciplinary Business Research (SIBR). 